\title{
The Eemian stage in the Netherlands: history, character and new research
}

\author{
J.H.A. Bosch ${ }^{1}$, P. Cleveringa ${ }^{2,3}$ \& T.Meijer ${ }^{2,4}$ \\ 1 Corresponding author; Netherlands Institute of Applied Geoscience TNO - National \\ Geological Survey, Geo-Mapping North and East Netherlands, P.O.Box 511, NL-8000 \\ AM ZWOLLE, the Netherlands; e-mail: a.bosch@,nitg.tno.nl \\ 2 Netherlands Institute of Applied Geoscience TNO - National Geological Survey, Geo- \\ logical Laboratory, P.O.Box 80015, NL-3508 TA UTRECHT, the Netherlands \\ ${ }^{3}$ e-mail: p.cleveringa@nitg.tno.nl \\ ${ }^{4}$ e-mail: t.meijer@nitg.tno.nl
}

Received: 1 February 2000; accepted in revised form: 13 April 2000

\begin{abstract}
A historical outline of the Eemian research in the Netherlands is presented as an introduction to recent research in the type area. At the end of the 19 th and during the first part of the 20th century, Eemian sediments were recognized because of the presence of lusitanian and mediterranean mollusc species. From 1930 onwards, pollen analysis made it possible to identify also non-shell-bearing deposits and to equate them with the Eemian. At the same time this technique proved a valuable tool for understanding the vegetation development during this interglacial. Pollen zonation offered a unique possibility for the correlation of terrestrial sequences in North-West Europe.

The type area of the Eemian, near Amersfoort, was described by Harting in 1874 and was comprehensively restudied by Zagwijn (1961). A pollen zonation was introduced as a standard for the Netherlands, allowing the correlation of pollen records from both marine and non-marine depositional environments. This enabled a more detailed temporal resolution, resulting in a better understanding of the distribution of the various environments in the type area.

In the northern and central parts of the Netherlands, the identification of the marine sequence was, apart from the occurrence of the specific mollusc fauna, facilitated by the presence of a till of Saalian age underlying the Eemian deposits. The presence of deep glacial basins in these areas enabled the deposition and preservation of a complete Eemian record in a marine setting. Sediment accumulation in the basins began immediately following deglaciation at the end of the Saalian. The Eemian type sections at Amersfoort are situated near the margin of one of these basins.

Recent research of the Eemian focused on the integration of lithostratigraphic evidence and information on the sedimentary environment as derived from diatoms, dinoflagellates, foraminifers, molluscs and pollen.
\end{abstract}

Keywords: Eemian, interglacial, research history, the Netherlands, stratigraphy

\section{Introduction}

The term 'Eemian' was first applied as a stratigraphical unit over 125 years ago (Harting, 1874, 1875). Harting (1852), who examined the subsoil of the Amsterdam and Amersfoort areas, noticed the consistent occurrence of clays and sands rich in mollusc and diatom fossils. The presence of lusitanian and mediterranean mollusc species in these sediments attracted the attention of geologists both within and beyond the Netherlands. More recently, geological mapping and multidisciplinary investigation of the micro- and macrofossils of both marine and non-marine Dutch Eemian deposits resulted in environmental information concerning their distribution and facies.

Although Amersfoort was subsequently assigned as the type locality of the Eemian interglacial stage, a comprehensive study integrating the various lines of geological evidence has, until now, not been carried out. The need for such a synthesis became particularly apparent when, in 1995, Prof. G. Richmond, the then chairman of the INQUA Commission on Strati- 
graphy, invited the then Geological Survey of the Netherlands (Rijks Geologische Dienst: RGD) to present data on the Eemian stage in a form that could be used for definition of the Middle/Late Pleistocene subseries boundary. This resulted in a reinvestigation of the Amersfoort stratotype locality accompanied by an investigation of a new borehole at the Amsterdam Terminal site, the reports of which are presented in the present volume (De Gans et al., 2000; Van Leeuwen et al., 2000; Cleveringa et al., 2000).

The present contribution is an introduction to the new research in the Eemian type area. It starts with a summary of the historical development of the research on the last interglacial sediments in the Netherlands. This will be followed by a concise overview of the nature, character and distribution of Eemian-age deposits in the Netherlands, to end with a summary of the aims of the recent investigations that will be reported on in detail in future publications.

\section{History}

The first major description of soft-rock geology in The Netherlands was written by Harting (Fig. 1) in 1852 and dealt with the subsoil of Amsterdam. He devoted much attention to the mollusc and diatom species encountered in the clays and sands. In particu-

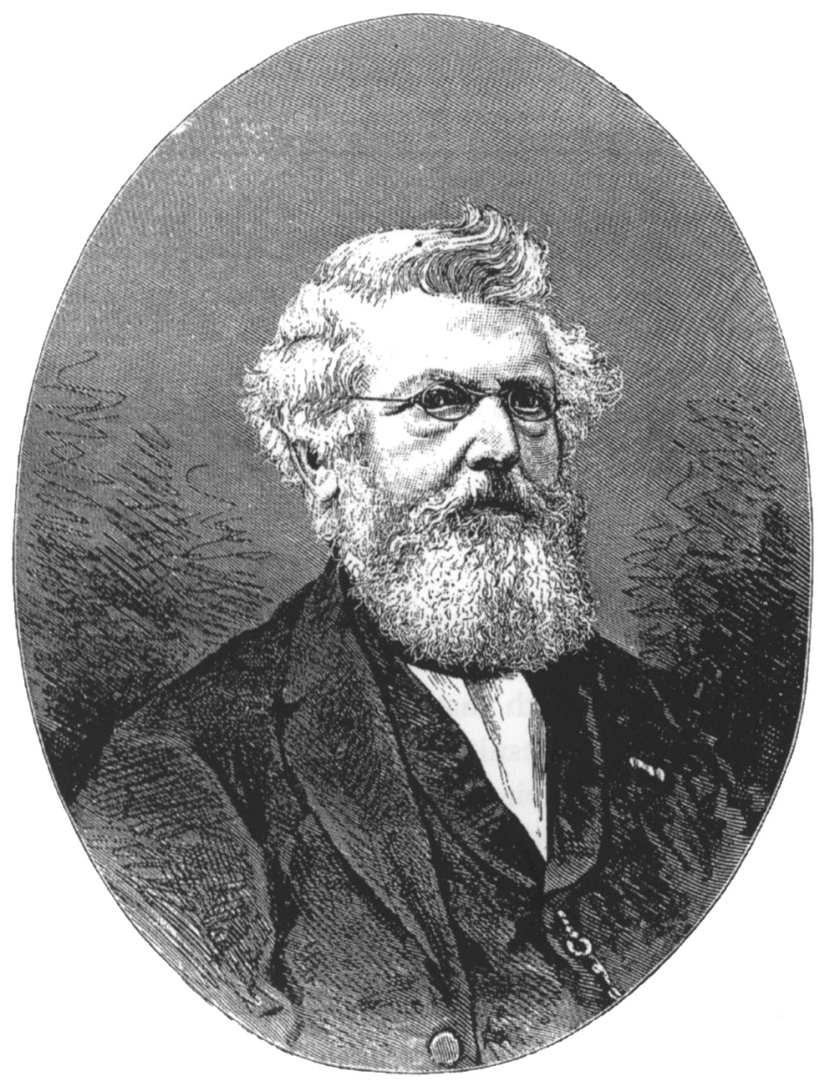

Fig. 1. Prof. Dr. P. Harting, founding father of the Eemian. lar the co-occurrence of fresh-water and marine diatoms attracted his attention. Two decades later he investigated an area near Amersfoort, where he found a fauna of marine shells at depths of around $17 \mathrm{~m}$ below the surface in sequences consisting of peat, fresh-water and salt-water clay and clayey sand. $\mathrm{He}$ was unable to correlate this unit with the then wellknown Belgian mollusc-based stratigraphical scheme of Dumont, who introduced units such as the Scaldisien and Poederlien. Several of the species Harting found (he mentioned particularly Cerithium lima and Venus rotundata, now classified as Bittium reticulatum, resp. Venerupis aurea) do not occur on the Dutch coast at present as they prefer warmer, lusitanian and even mediterranean seas. He introduced therefore a new stratigraphical unit, which he named 'Eemian', after the Eem stream (Harting, 1874 [in Dutch], 1875 [in French], cf. Fig. 2). In hindsight he concluded that he had also found the same stratigraphical unit beneath Amsterdam.

At the time of Harting's publications, a diluvial genesis - invoking drift ice - was generally accepted as explanation of the presence of Scandinavian boulders in the deposits underlying the Eemian sequence in the northern parts of The Netherlands, as well as in Germany and Denmark. The glacial theory was first presented in the Netherlands by Van Calker in a lecture, held in 1881. Harting (1875) had interpreted the Nordic stones occurring in the loam below the Eemian deposits as relicts of transport by ice rafting. Ten years later, Lorié (1887) recognized the boulder clay, often occurring below Eemian deposits, as a product of the Scandinavian ice sheet that had covered half of the Netherlands during the penultimate glaciation.

The Eemian was recognized also outside the Low Countries. Nordmann (1908) described Eemian shell-bearing deposits in his native country, Denmark, and compared them with similar deposits in north-western Germany and the Netherlands. During a visit to the Netherlands he studied the Harting shell collection at Utrecht University with Lorié. The interest in this early period was mainly focused on the presence of several mediterranean and lusitanian mollusc species and on the wealth of the fauna.

Summarising the knowledge of the Eemian, Van Baren (1927) noticed [in translation by the present

continue. Oe qui est surtout caracteristique dans les denx cas, c'est la présenco da Cerilhium lima et do la Venus roltundata, qui ne font plus partie de notre faune. Ja formation dont il s'agit, située dans uo sol d'alluvion, au-dessns dn diluvinm, ne peut être rapportée a l'un des systémes pliocénes de Damont. On est donc en droit de la désigner sous un nom particulier, celui de système écmien. Fig. 2. The introduction of 'le système Éemien' (Harting, 1875). 
authors] 'that little was known of the quantitative as well as the qualitative distribution of molluses on a vertical (sequential) scale, the presence of foraminifera and diatoms, although already indicated by Harting (1852)'. The following decade was to introduce several new fields of study.

\section{Stratigraphical position}

The stratigraphical terminology in use for the Quaternary in north-western Europe was derived from the Alps. Penck \& Brückner (1901/1909) had used there flights of river terraces, connected to ice-marginal positions, to identify and name glacials. The two most recent glacials were named 'Riss' and 'Würm'; the Eemian was consequently often referred to as the 'Riss-Würm Interglacial'. Likewise the sediments were also named following the Alpine terminology; the fluvial terraces were classified as Lower, Middle and High Terrace. Following the recommendations of the Geological Congress of London (1948), stratigraphy gained a sounder basis. Van der Vlerk \& Florschütz (1950 [in Dutch], 1953 [in English]) published a new regional biostratigraphical scheme and nomenclature for the subdivision of the Quaternary in the Netherlands to replace the alpine terminology. The latter, essentially of morphostratigraphical origin, was generally applied chronostratigraphically on a supraregional scale. Instead, palynological zonations (i.e., biostratigraphy) were used to correlate over larger areas from that time onwards.

As had been demonstrated by Jessen \& Milthers (1928) in an extensive series of pollen investigations, a period of widespread Corylus and Carpinus woodland (pollen zones $f$ and $g$ ) was present during the Eemian in Denmark, separating intervals with an open vegetation of mere steppe vegetation (Fig. 3). The Eemian forest development was shown by Louman (1934), using pollen analysis in the Netherlands for the first time. As she studied peat layers on top of the regressive marine Eemian sequence, Picea, Pinus and Abies were found in the majority of her samples. Moreover, Florschütz (1930) described plant macrofossil remains found at Eefde in the IJssel valley. His list contained mainly (Weichselian) steppe plants but also those of a temperate climate (Eemian), in particular waterplants.

Presenting a series of pollen sequences of Eemian deposits, Van der Vlerk \& Florschütz (1950) named the last interglacial formally as the Eemian, a national stratigraphical unit. This national stratigraphical scheme was soon abandoned, however, in favour of the scheme used for North Germany, where the younger cold interval was named 'Weichselian' and the penultimate glacial 'Saalian' (cf. Woldstedt, 1950).

In support of the development of the radiocarbon technique at Groningen University, the Geological Survey started a project in 1956 in the Eemian type area near Amersfoort, particularly known for the occurrence of Eemian peat beds. Because natural conta-

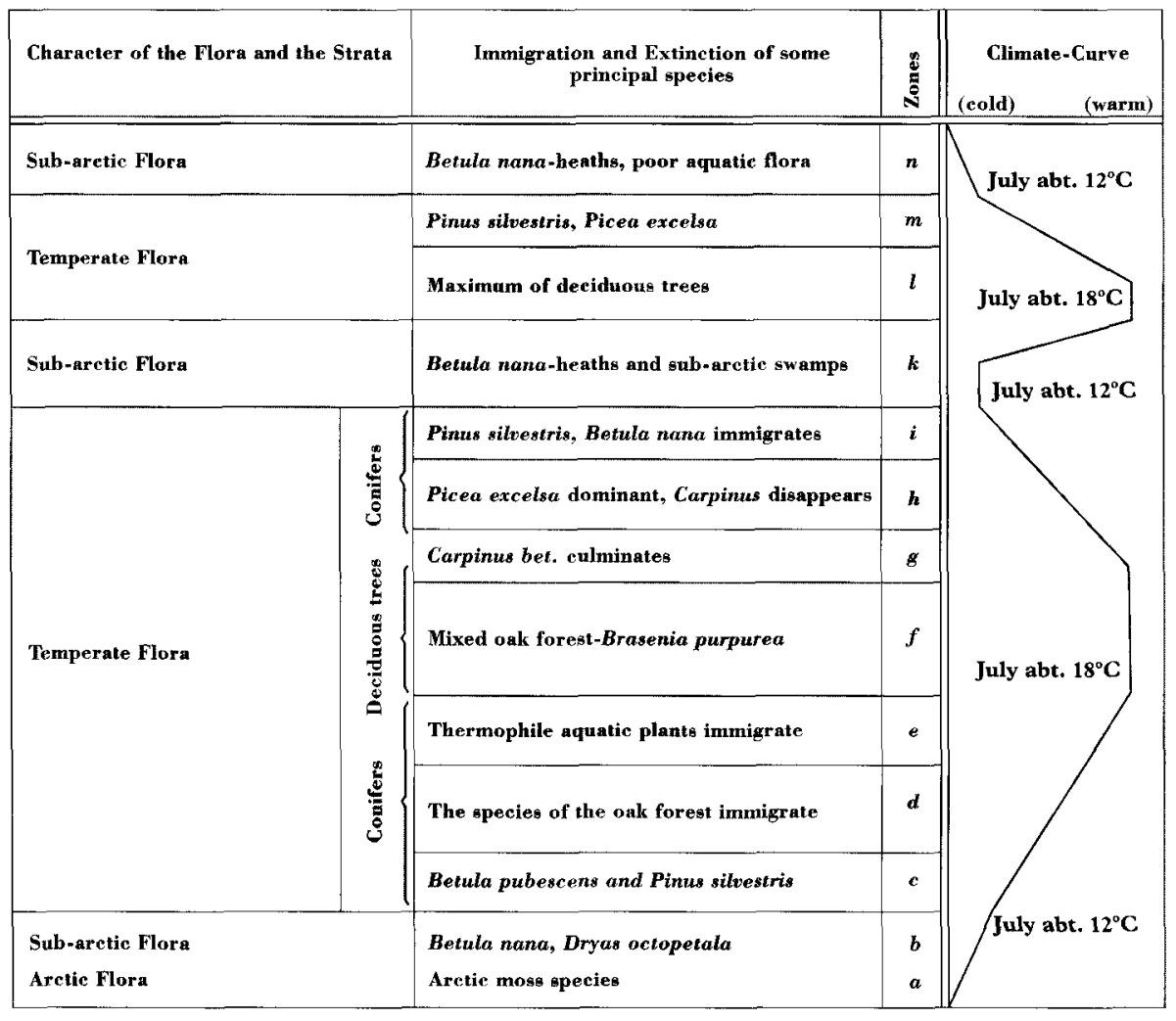

Fig. 3. Pollen zonation of the Eemian stage in Denmark (simplified after Jessen \& Milthers, 1928). 
mination, caused by roots from higher levels in earlier samples, had resulted in erroneously young dates, deeper deposits in the Eem valley were core-sampled and dated (De Vries, 1958). None of the uncontaminated Eemian samples, nor some of the early Last Glacial samples, contained any measurable C-14; all samples gave ages of $>53000$ years BP. Unfortunately, it proved impossible to date Eemian and Early Weichselian material with the C-14 technique.

In his Amersfoort study, Zagwijn (1961) presented a scheme of the Eemian pollen zones for the Netherlands (Fig. 4). It is based essentially on the Jessen \& Milthers (1928) zonation. Apart from the Betula zone, all pollen zones are present in the Amersfoort boreholes. Two decades later, Miller \& Mangerud (1985) determined amino-acid racemisation (AAR) rates on marine shells from the Amersfoort borehole. Together with AAR data from other 'secure' Eemian material (such as the Bergen, Castricum and Zunderdorp boreholes), it formed the basis for correlation of
Pleistocene marine deposits in North-Western Europe. The authors concluded that the Eemian should be exclusively correlated with marine isotope stage (MIS) $5 \mathrm{e}$ in the ocean-core sequences.

\section{Characteristics, distribution and facies of the Dutch Eemian}

The Scandinavian ice sheet, which reached the Netherlands during the Saalian, had a great impact on the regional topography. As Lorié (1906) had already noticed in the Amersfoort area, deposits had been relocated by the action of the glacial ice. Lobes at the margin of the ice sheet had created tongue-like basins as deep as $100 \mathrm{~m}$, and ice-pushed ridges as high as $100 \mathrm{~m}$. After the ice had melted, the basins acted as large sediment traps. Saalian sediments consisted of a layer of only a few metres thick in most of these basins. Only the basin between Arnhem and Zwolle, the present valley of the Gelderse IJssel, had

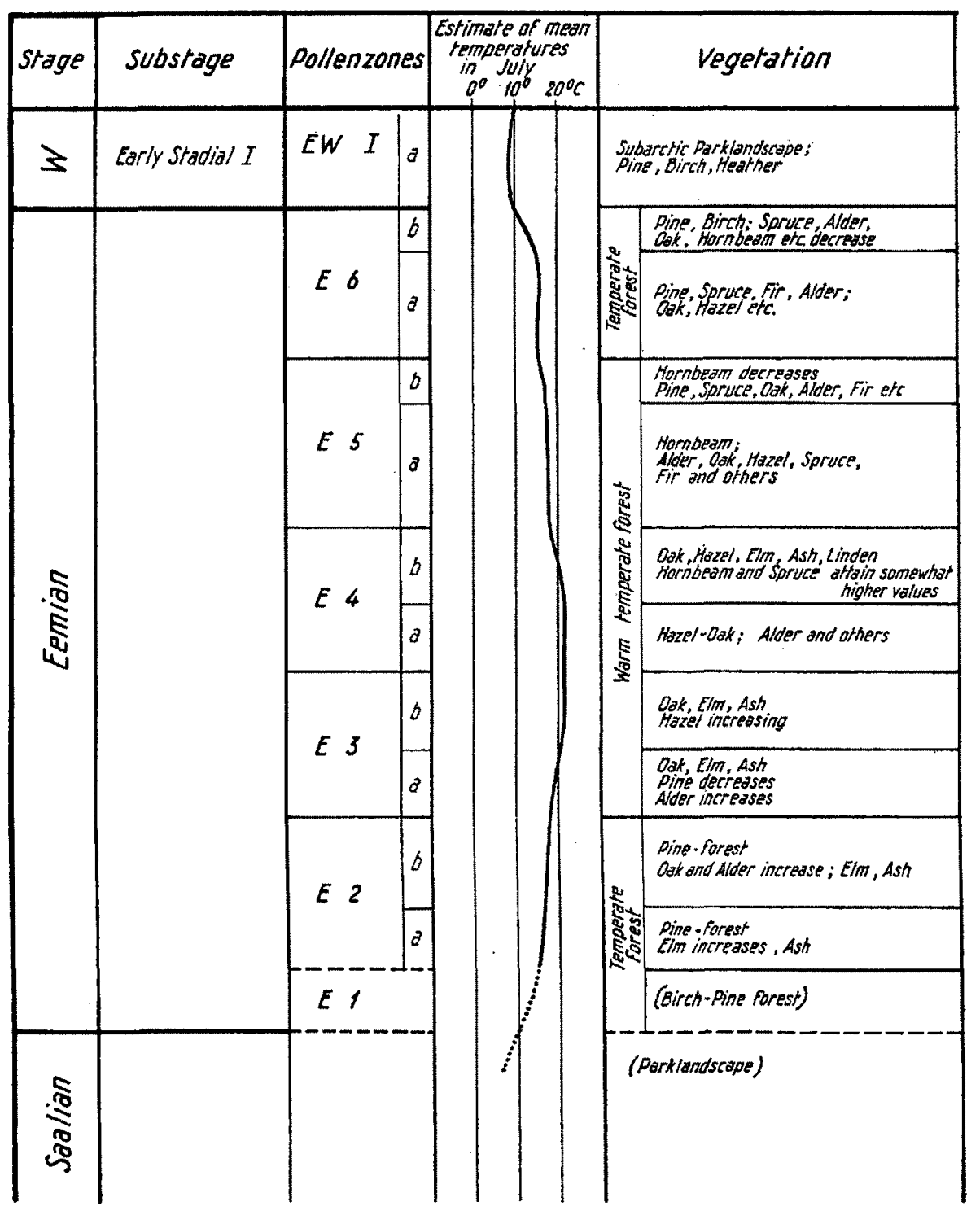

Fig. 4. Pollen zonation of the Eemian stage in the Netherlands (Zagwiin, 1961). 


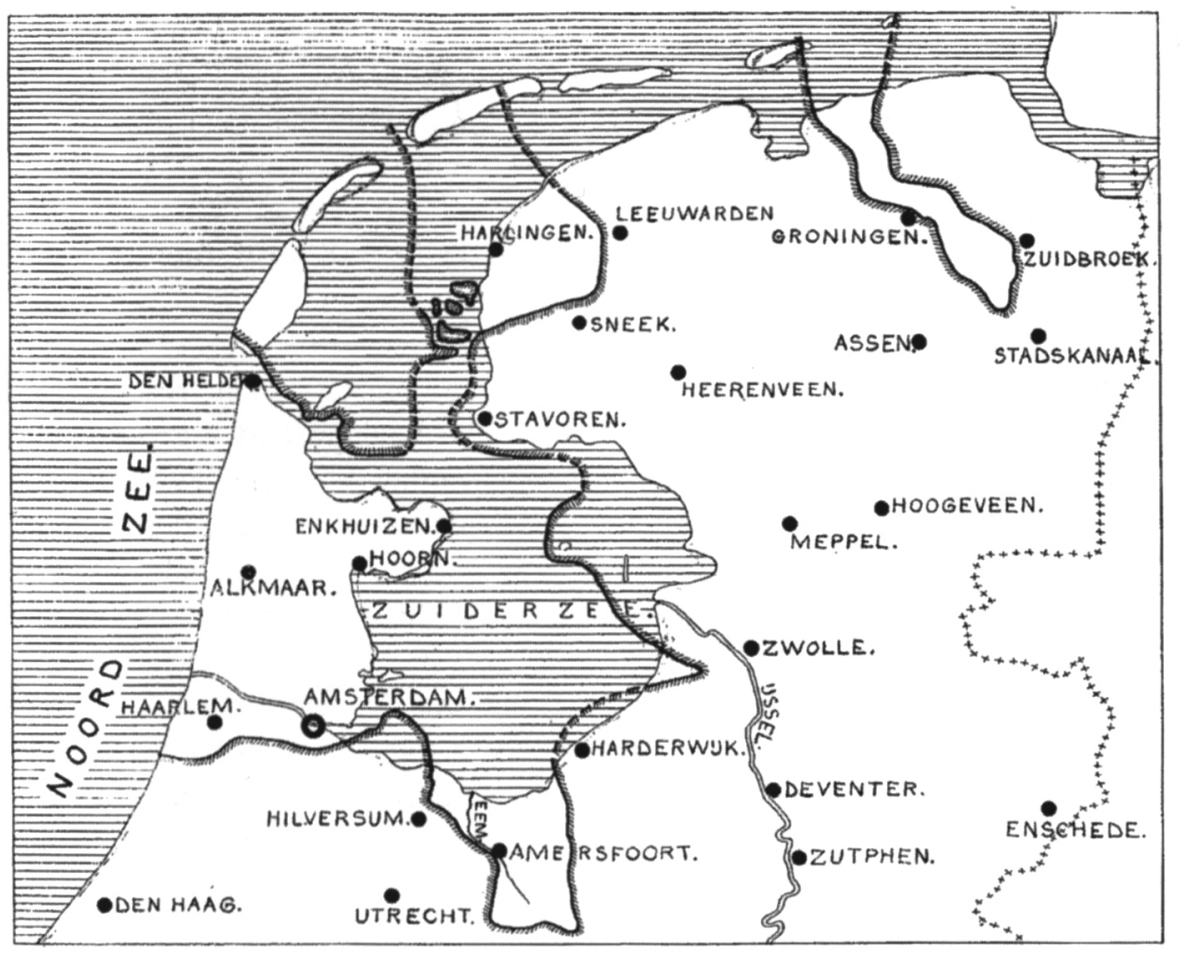

Fig. 5. Coastline of the Eemian North Sea (Steenhuis, 1933).

been filled up by the Rhine during the late Saalian. This basin had acted as a large prodelta lake and had already been filled at the start of the Eemian.

A map showing the Eemian coastline in the northern and central part of the Netherlands was published by Steenhuis (1933) (Fig. 5). The distribution area corresponds very closely with that based on present knowledge of the occurrence of Eemian marine deposits. For the South-Western coastal zone, the author stated that Eemian molluscs do not occur in situ but had been reworked during the subsequent glacial. In the mid-thirties, a sound basis was laid, both geographically and stratigraphically, for a further study of the Eemian sediments. This only concerned marine and perimarine deposits, however: fluvial and other non-marine deposits had been recognized only on a limited scale. After World War II, Burck (1949a) added data on the distribution of fluvial deposits. Only 25 years later, a first national synthesis of Eemian terrestrial peat occurrences was presented in a compilation of all Quaternary lithostratigraphical units distinguished in the Netherlands (Doppert et al., 1975).

From 1950 onwards, much information on Eemian sediments has been collected during the systematic mapping projects of the RGD, as well as during other geological studies. At present the database of the National Geological Survey (NITG-TNO) contains descriptions of approx. 80,000 boreholes deeper than $10 \mathrm{~m}$, about 6.000 of which are estimated to contain deposits of Eemian age. The distribution map of these deposits (Fig. 6) is directly derived from this database.
Identification of the marine facies is commonly easy because of the presence of the typical Eemian mollusc fauna and because of its stratigraphical position overlying Saalian glacial deposits, the latter consisting partly of till. Moreover, many boreholes with Eemian deposits have been analysed for their pollen, diatom, mollusc and foraminifer content.

In the following sections, the three major sedimentary environments (fluvial, other non-marine [soils and peats], and marine) of the Dutch Eemian will be summarized.

\section{Fluvial environment}

Burck (1949a) identified clay and peat beds in the area of the present Gelderse IJssel, which he correlated with the marine Eemian deposits in the former Zuiderzee area (see Fig. 5). The section (Fig. 7) shows the position of this unit, occurring between Saalian deltaic and Weichselian fluvial coarse-grained deposits. By the end of the Saalian, sediments of the Rhine river had filled the entire IJssel glacial basin. The course of the Rhine during the Eemian has been discussed by Van de Meene \& Zagwijn (1978). After the ice had melted, the river waters followed a path to the north, turning to the west and aligned through the so-called Vecht valley towards the North Sea (Fig. 6).

In the present IJssel valley, many clay and peat beds are attributed to the Eemian (Van de Meene, 1979). The thickness of these deposits remains limited to 3-5 $\mathrm{m}$, although channel fills of over $10 \mathrm{~m}$ are found locally. 


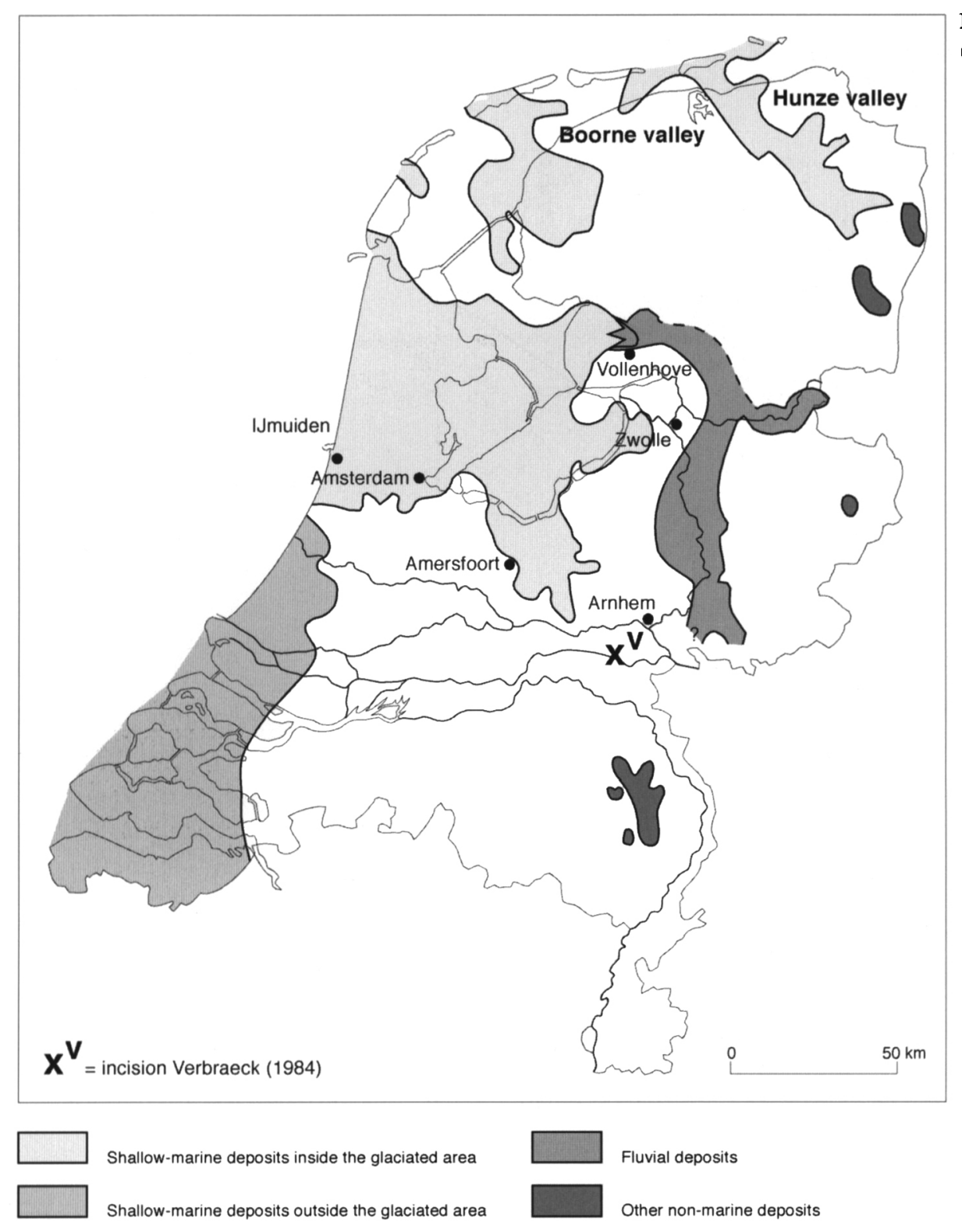

Fig. 6. Distribution of Eemian deposits (Doppert et al., 1975; Van de Meene, 1979; Dijkshoorn \& Pagnier, 1995).

Only limited palynological material has been published from the riverine area. Van der Vlerk \& Florschütz (1953) described the Zwartewater section, in the IJssel valley north of Zwolle. This sequence showed the presence of a characteristic Alder (Alnus) brook over a longer timespan (Fig. 8). At the top of the diagram, enclosed in a zone characterized by $\mathrm{Pi}$ nus, a supposedly warmer interval is present. Looking at the lithology, it was later realized that the 'warmer' interval is embedded in reworked sands (Zagwijn, 1961).

Verbraeck (1984) suggested that Eemian fluvial deposits are present in a relatively narrow incised channel in the Betuwe area as part of post-Saalian Rhine sediments (Fig. 6). This attribution was based mainly on circumstantial evidence. Although geological mapping has been quite intense in the former fluviatile area, occupying a surface of $100 \times 35 \mathrm{~km}^{2}$, no pollen or other biostratigraphical analyses are available to support this view. The present authors interprete the sediments described by Verbraeck (1984) as Saalian Rhine deposits, formed during the timespan when ice blocked the course of the river in a northerly direction.

\section{Soils and peats}

Outside the areas of marine and fluvial sedimentation, soils and peats were formed during the Eemian. Vegetation, for the main part temperate forests, flourished under favourable climatic circumstances. Contemporaneous soils were, however, only rarely preserved. Soils have been reported from the loess of South Limburg (Kuyl, 1980) and from local fluvial deposits (Huijzer \& Mücher, 1993).

Eemian peats have been better preserved. These 


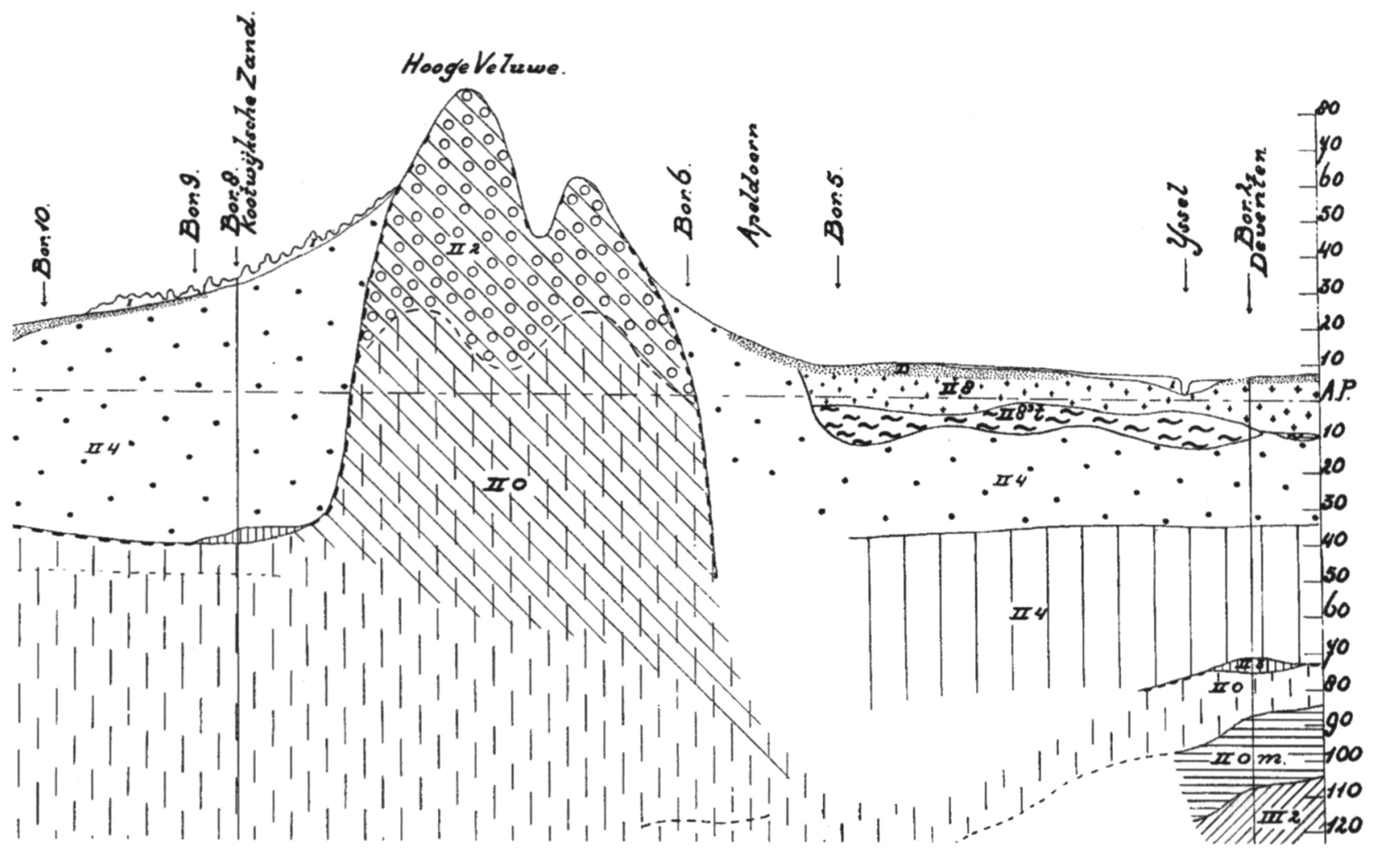

I Holocene fluvial deposits

Weichselian aeolian coversands

II8. Weichselian periglacial deposits

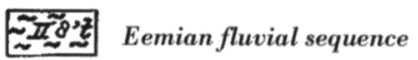

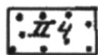

II24

Saalian deltaic sequence (Rhine)
Middle Pleistocene fluvial deposits (Rhine)

Lower Pleistocene fluvial deposits (Baltic system)

Lower Pleistocene marine deposits

Pliocene marine deposits

Fig. 7. Section through the Deventer glacial basin, showing the position of the Eemian fluvial sequence (after Burck, 1949b). Vertical exaggeration 100x. AP (Amsterdam Ordnance Level) scale, in meters above/below sea level.

Legend: $\mathrm{I}=$ Holocene fluvial deposits. II = Weichselian aeolian coversands. II $8=$ Weichselian periglacial deposits. II $8^{\prime} \mathrm{t}=$ Eemian fluvial succession. II $4=$ Saalian deltaic succession (Rhine). II $2=$ Middle Pleistocene fluvial deposits (Rhine). II 0 = Early Pleistocene fluvial deposits (Baltic system). II 0m = Early Pleistocene marine deposits. III 2 = Pliocene marine deposits.

peats, often starting as a hydromorphic soil, were fossilized not only in the lower parts of the landscape, but also on water divides. In the southern part of the country, especially in the Peel area, a few meters of Eemian oligotrophic peat is present. Interglacial pollen sequences were demonstrated for the first time by Florschütz \& Anker-van Someren (1956). Because of the particular, mainly oligotrophic, environmental conditions, the interpretation of the pollen zones is not straightforward but their Eemian age was convincingly demonstrated.

In the northern part of the Netherlands, the area overriden by glacial ice during the Saalian, the topography was much more pronounced during the Eemi- an than during the Holocene. Higher drainage gradients prevented the formation of extensive peat deposits; no peats have been preserved on the former water divides. Local depressions and the upper reaches of incised river courses offered space for the formation of organic material. The results of several of these finds, in a stratigraphical sense very fragmentary, have been reported from the northern and eastern Netherlands (De Gans, 1981; Van Geel et al., 1986, 1995; Zagwijn, 1996). Data from the classical Vollenhove site were published by Van der Vlerk \& Florschütz (1953). This site, in a depression within glacial till, comnsists of a thin peat bed containing fruits of Brasenia purpurea; a waterlily not known from the 


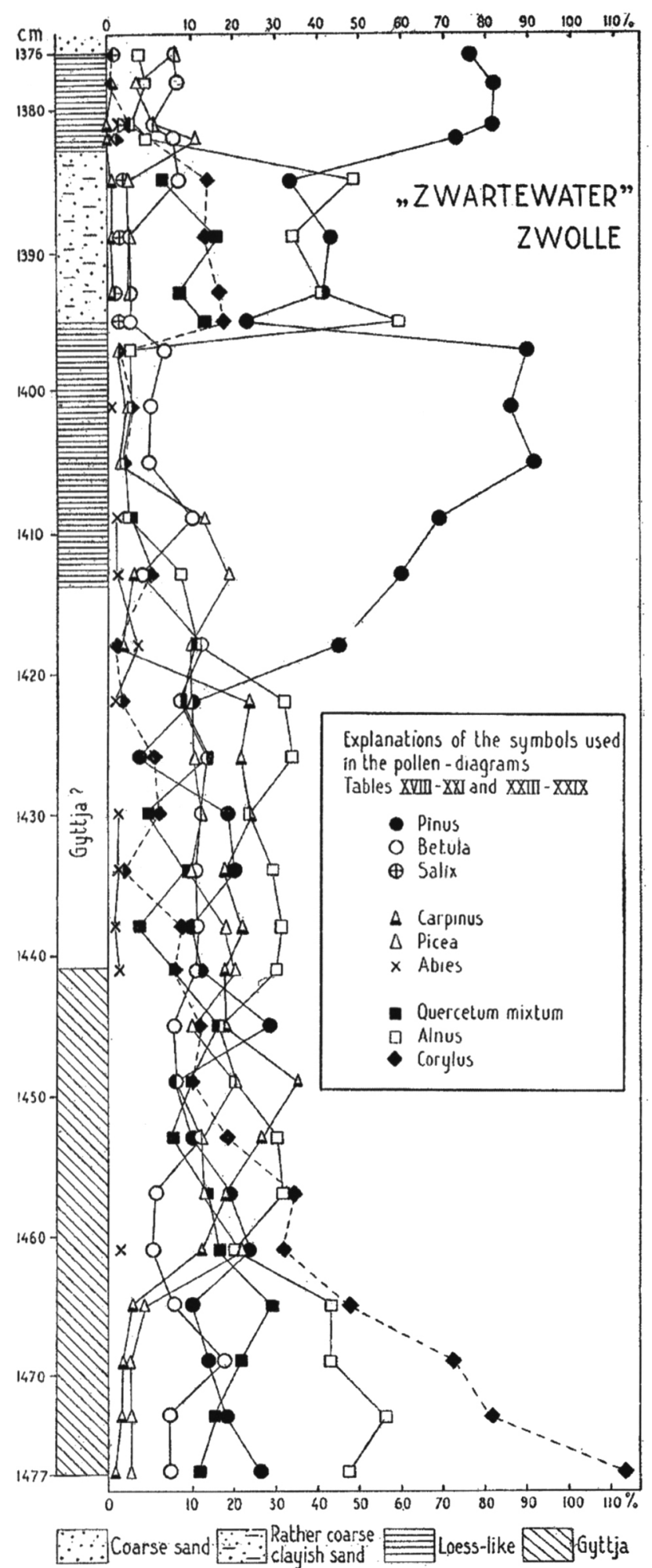

Fig. 8. Pollen diagram of the Eemian fluvial sequence at Zwolle, Zwartewater borehole (Van der Vlerk \& Florschütz, 1953).

Holocene in the Netherlands was recovered here. Jessen \& Milthers (1928) had previously identified Brasenia in Denmark (Fig. 3) and had interpreted it as an indicator of higher summer temperatures. Vollenhove is the only place in the Netherlands where Eemian sediments were ever found at the surface. The section dates from the early Eemian, with the Betula, Pinus and Quercus pollen zones. It was the only published section showing the Betula zone, the lowermost Eemian pollen zone, for decades.

\section{Marine environment}

The distribution of Eemian marine sediments is restricted to three areas (Fig. 6):

(1) The first area, in the northern part of the Netherlands, is inside depressions of the local rivers Boorne and Hunze, which were incised during the later part of the Saalian. Marine sediments were deposited in these incisions; they wedge out against the Frisian/Drenthe till plateau. Locally, the deposits reach a thickness of 15-20 m.

(2) The second area is found in the central part of the Netherlands, where a wide basin was present. The sedimentary conditions resembled those in the northern area. On the southern fringe, however, freshly carved glacial basins surrounded by ice-pushed hills acted as sediment traps. A series of major basins is present from IJmuiden at the present North Sea coast up to the valley of the IJssel river between Zwolle and Arnhem. The maximum thickness of the Eemian deposits in this area is about $70 \mathrm{~m}$, with a mean thickness of about $20 \mathrm{~m}$.

(3) In the third area, in the south-western part of the Netherlands outside the limit of the Saalian glaciation, sediments with marine shells are present, consisting mainly of coarse shelly sands with gravet. In comparison to the former areas, the absence of clay and, less obvious, peat layers is striking. Besides this lithological difference, it is clear from AAR data that more than one marine horizon can be distinguished. The horizons belong not only to the Eemian but to older interglacials as well (Meijer \& Cleveringa, in prep.). The mean sediment thickness is approx. $10 \mathrm{~m}$.

Harting's data from Amsterdam, published in 1852, and those from Amersfoort, published in 1874 and 1875, were obtained from two glacial basins separated from each other by an ice-pushed ridge. The more important information from the deeper (more complete) part of these basins stems from Amsterdam, where Zagwijn (1983) described an Eemian clay sequence that is much thicker than the one at Amersfoort. A nearly full palynological record of the Eemian was found on top of Saalian lacustrine silts. Diatom studies of the same cores (De Wolf \& Cleveringa, 1994) mention important changes in the sedimentary environment of the Amsterdam basin. At the end of the Saalian, the basin contained a shallow lake, situ- 
ated north of the treeline. Early in the Eemian, a rapid rise of the water level initiated the infilling of the basin with fresh water. Preglacial deposits, forming the surface in the area north of the basin, were eventually overtopped by seawater. The marine influence changed the diatom flora considerably. At first, a gyttja was formed in brackish water; deposition of clay followed a little later and continued for the major part of the Eemian. A diatom flora indicative of shallow, clear seawater was fossilized during the early Eemian; it contains several species that are found at present in the Baltic Sea. In a second stage, species indicating warmer water appeared, with influxes of oceanic water. The last phase shows species that were also to occur in this area during the Holocene.

The boreholes at Amersfoort were situated at the margin of a glacial basin on the slope of the icepushed ridge. Van Voorthuysen (1958) published the results of the first foraminiferal studies of Eemian sediments after Harting (1852) had noted their presence. He demonstrated a sequence, starting with a very thin bed of fresh-water gyttja at the bottom, that changed into a marine gyttja, a thick layer of marine coarse sands, into lagoonal and finally estuarine clays in which the fresh-water influence increased towards the top. The energy conditions remained high and sands form consequently the main lithology. Because of undulations in the substrate surface, a thin clay layer indicating lagoonal conditions is locally present at the base of the sequence. As the depth of this part of the basin is restricted, the clay beds remain of limited thickness and are mainly present at the top of the unit. Engel (1958) discussed the presence of the echinoderm Echinocyamus pusillus in borehole Amersfoort 1 . He concluded that it lived on a coarse sandy substrate along the shoreline. Diatom and mollusc studies were performed at the Amersfoort cores as well but remained unpublished, preventing a balanced integrated study of depositional conditions in the basin.

\section{New research}

The data on distribution and facies presented above were available at the time the Eemian project was initiated. The main goal of the project was to carry out a broad study in which many disciplines would be involved, in order to base conclusions on a wide array of palaeo-environmental indications. After it had been decided not to rely on available material but to sample a new borehole in which the Eemian should be represented in optima forma, the following prerequisites were formulated:

(1) the presence of a thick sequence in which late
Saalian deposits pass gradually into Eemian sediments,

(2) a continuous sediment record through the entire Eemian.

It was obvious from these prerequisites that the borehole was to be drilled in one of the glacial basins, because these had acted as sediment traps after deglaciation. It was decided that the new borehole was to be located in the area of the Valkenweg holes of Zagwijn $(1983,1996)$. The new- cored borehole 'Amsterdam-Terminal' was successful. A 35-m succession of Eemian sediments was recovered, of which the main part were clays with excellently preserved organisms (Van Leeuwen et al., 2000). The main results are:

(1) a long record of pollen, starting after Saalian deglaciation, possibly only interrupted shortly at the transition from Saalian to Eemian, continuing up to the transition between the Carpinus and the Picea pollen zone (E5 to E6),

(2) an excellent record of macro- and micro-organisms and plants (molluscs, foraminifers, ostracods and diatoms), of grain-size distribution and of geochemical data, allowing a highly detailed reconstruction of changes in the sedimentary environment of the basin.

In conclusion, the presence of the glacial basins at the start of the Eemian was a first, and a relatively low rate of sedimentation was a second prerequisite for the excellent preservation of sediments. The position of the Amsterdam-Terminal borehole within the glacial basin, viz. far away from the most important sediment source (the North Sea) and at a similar distance from the slopes of the basin, warranted an even and uninterrupted infilling of this part of the basin. This infilling only ceased when the sea level dropped at the end of the Eemian so that the site became dry land.

For comparison, material of boreholes Amersfoort 1 and 2 (Van Voorthuysen, 1958; Zagwijn, 1961) the stratotype sections of the Eemian - was re-examined (Cleveringa et al., 2000). New data, particularly the occurrence of Taxus, and the integrated interpretation of foraminifers, diatoms and molluscs, were evaluated against the new data from the AmsterdamTerminal borehole. In this way changes in terms of local and regional factors in the composition of flora and fauna could be interpreted in a more meaningfull way.

Correlation of this material with that of Amsterdam-Terminal yields a better basis for understanding the sedimentary continuity, or rather its discontinuity, in the Amersfoort area. When peat deposition took over during the late Eemian, however, the registration 
in the Amersfoort area was - contrary to the Amsterdam site - very good. The reconstruction of the Eemian sedimentation profits greatly from the presence of different sedimentary environments; when deposition stopped at one locality, it increased at another. As mentioned by De Gans et al. (2000), the relief of the pre-existing surface and the paleogeographical situation were significant factors, controlling the sedimentation processes during the Eemian in this area. By contrast, the sedimentation during the Holocene took place under conditions that were quite different: when extensive formation of peat was propagated by a very gently sloping sandy substrate. Peat is virtually absent at the base of the Eemian sequence.

\section{Future research}

Although the availability of extensive new evidence enables Quaternary scientists to improve the reconstruction of sedimentary processes and the underlying conditions, the knowledge of the non-marine area is still limited. A first goal for future work will be the collection of more data from the fluvial and inland peat areas. Secondly, in order to investigate conditions during the initial and the late phases of marine sedimentation, work must be undertaken on the lower and upper parts of the glacial-basin fills. The influence of oceanic circulation, such as from the North Sea through the Baltic to the White Sea, on floral and faunal elements could thus be elucidated.

\section{Acknowledgements}

The inspirator and initiator of this project was Thijs van Kolfschoten. We thank him for his perseverance and his patience. Secondly, we thank the staff of the Rijks Geologische Dienst, later the Netherlands Institute of Applied Geoscience TNO, who took part in the project; in drilling, laboratory, secretarial and managing work, in analyzing, and in drawing (not only for the present contribution but for other presentations resulting from this project as well). Thanks to their efforts a huge amount of work could be done efficiently in the short time available for this project.

Colleagues of Utrecht University, the Vrije Universiteit van Amsterdam and the University of Cambridge are thanked for joining the project and for sharing their facilities and knowledge in several fields of study.

\section{References}

Burck, H.D.M., 1949a. Continentale Eemlagen in het dal van den Gelderschen IJssel. Verhandelingen Koninklijk Nederlands
Geologisch Mijnbouwkundig Genootschap, Geologische Serie 15: 32-43.

Burck, H.D.M., 1949b. Geologisch profiel Breukelen-Deventer. Mededelingen Geologische Stichting, Nieuwe Serie 3: 5-17.

Cleveringa, P., Meijer, T., Van Leeuwen, R.J.W., De Wolf, F., Pouwer, R. Lissenberg, T. \& Burger, A.W., 2000. The Eemian type locality at Amersfoort in the central Netherlands: redeployment of old and new data. In: Van Kolfschoten, Th. \& Gibbard, P.L. (eds.): The Eemian - local sequences, global perspectives. Geologie en Mijnbouw / Netherlands Journal of Geosciences 79 (2/3) (this issue).

De Gans, W., 1981. Stratigraphy, palynology and radio carbon data of Eemian and Early Weichselian fluvial deposits in the Drentsche Aa valley system (Drente, The Netherlands). Geologie en Mijnbouw 60: 193-202.

De Gans, W., Beets, D.J. \& Centineo, M.C., 2000. Late Saalian and Eemian deposits in the Amsterdam glacial basin. In: Van Kolfschoten, Th. \& Gibbard, P.L. (eds.): The Eemian - local sequences, global perspectives. Geologie en Mijnbouw / Netherlands Journal of Geosciences 79: 147-160 (this issue).

De Vries, H., 1958. Radiocarbon dates for upper Eem and Würminterstadial samples. Eiszeitalter und Gegenwart 9: 10-17.

De Wolf, H. \& Cleveringa, P., 1994. Eemian diatom floras in the Amsterdam glacial basin. Proceedings $13^{\text {th }}$ International Diatom Symposium: (Maratea, 1994): 489-505.

Dijkshoorn, L. \& Pagnier, H., 1995. Landelijk hydrogeologisch model. Internal report Rijks Geologische Dienst (Heerlen) GB 2504: $11 \mathrm{pp}$.

Doppert, J.W.Chr., Ruegg, G.H.J., Van Staalduinen, C.J., Zagwijn, W.H. \& Zandstra, J.G., 1975. Formaties van het Kwartair en Boven-Tertiair in Nederland. In: Zagwijn, W.H. \& Van Staalduinen, C.J. (eds.): Toelichting bij geologische overzichtskaarten van Nederland. Rijks Geologische Dienst (Haarlem:): 11-56.

Engel, H., 1958. Echinocyamus pusillus (O.F. Muller). Mededelingen Geologische Stichting, Nieuwe Serie 11:41-42.

Florschütz, F., 1930. Fossiele overblijfselen van den plantengroei tijdens het Würmglaciaal en het Riss-Würminterglaciaal in Nederland. Proceedings Koninklijke Akademie van Wetenschappen (Amsterdam) 33: 1043-1044.

Florschütz, F. \& Anker-van Someren, A.M.H., 1956. Het JongKwartair op de Peelhorst en in de westelijk van de Horst gelegen Grote Slenk, de palynologische resultaten. Mededelingen Geologische Stichting 10: 55-65.

Harting, P., 1852. De bodem onder Amsterdam onderzocht en beschreven. Verhandelingen $1^{\mathrm{e}}$ klas Koninklijk Nederlands Instituut van Wetenschappen, $3^{\mathrm{e}}$ Reeks 5: 73-232.

Harting, P., 1874. De bodem van het Eemdal. Verslagen en Verhandelingen Koninklijke Academie van Wetenschappen, $2^{\mathrm{e}}$ Reeks 8: 282-290.

Harting, P., 1875. Le système Éemien. Archives Néerlandaises Sciences Exactes et Naturelles de la Societé Hollandaise des Sciences (Harlem ) 10: 443-454.

Huijzer, A.S. \& Mücher, H.J., 1993. Micromorphology of the intraSaalian interglacial pedocomplex and Eemian Rocourt soil in the Belvédère pit (Maastricht, The Netherlands). Mededelingen Rijks Geologische Dienst 47: 31-39.

Jessen, A. \& Milthers, V., 1928. Stratigraphical and paleontological studies of interglacial freshwater deposits in Jutland and Northwest Germany. Danmarks Geologiske Undersøgelse 48: 1-379.

Kuyl, O., 1980. Blad Heerlen (62W, 62O). Toelichtingen bij de geologische kaart van Nederland 1:50.000. Rijks Geologische Dienst (Haarlem:): 206 pp.

Lorié, J., 1887. Contributions a la géologie des Pays Bas II. Le Diluvium ancien ou graveleux. Archives du Musée Teyler, Serie II, Volume 1, Partie 3: 1-103. 
Lorié, J., 1906. De geologische bouw der Geldersche Vallei, benevens beschrijving van eenige nieuwe grondboringen, VII. Verhandelingen Koninklijke Akademie van Wetenschappen (Amsterdam), Sectie 2, Deel 13:100 pp.

Louman, G.G., 1934. On the occurrence of interglacial (RiszWürm) peat in Holland. Proceedings Koninklijke Akademie van Wetenschappen 37:22-27.

Meijer, T. \& Cleveringa, P. (in prep.). Amino stratigraphy of Middle and Late Pleistocene deposits in The Netherlands. Quaternary Science Reviews.

Miller, G.H. \& Mangerud, J., 1985. Aminostratigraphy of European marine interglacial deposits. Quaternary Science Reviews 4: 215-278.

Nordmann, V., 1908. Molluskenfaunaen i Cyprinaleret og MellemEuropas andre Eem-aflejringer. Studier over interglaciale aflejringer i Danmark, Holland og Nord-Tyskland. Ph.D thesis København Univ.: 159 pp.

Penck, E. \& Brückner, E., 1901/1909. Die Alpen im Eiszeitalter. Tauschnitz (Leipzig), 3 volumes: 1199 pp.

Steenhuis, J.F., 1933. De kustlijn der Eemzee op Nederlandsch gebied. De Ingenieur 41: 194-195.

Van Baren, J., 1927. De bodem van Nederland II, Het Kwartair. Van Looy (Amsterdam): 1365 pp.

Van de Meene, E.A., 1979. Het ontstaan van de Geldersche IJssel. Geografisch Tijdschrift 13: 202-210

Van de Meene, E.A. \& Zagwijn, W.H., 1978. Die Rheinläufe im deutsch-niederlandischen Grenzgebiet seit der Saale-Kaltzeit. Überblick neuer geologischer und pollenanalytischer Untersuchungen. Fortschritte in der Geologie von Rheinland und Westfalen 28: 345-359.

Van der Vlerk, I.M. \& Florschütz, F., 1950. Nederland in het IJstijdvak. De Haan (Utrecht): $289 \mathrm{pp}$.

Van der Vlerk, I.M. \& Florschütz, F., 1953. The palaeontological base of the subdivision of the Pleistocene in The Netherlands. Verhandelingen Koninklijke Akademie van Wetenschappen,
Afdeling Natuurkunde 1, XX: 1-58.

Van Geel, B., Klink, A.G., Pals, J.P. \& Wiegers, J., 1986. An Upper Eemian lake deposit from Twente, eastern Netherlands. Review of Palaeobotany and Palynology 47: 31-61.

Van Geel, B., Pals, J.P., Van Reenen, G.B.A. \& Van Huissteden, J., 1995. The indicator value of fungal remains, illustrated by the palaeoecological record of a Late Eemian/Early Weichselian deposit in the Netherlands. Mededelingen Rijks Geologische Dienst 52: 297-316.

Van Leeuwen, R.J.W., Beets, D., Bosch, J.H.A., Burger, A.W., Cleveringa, P., Van Harten, D., Herngreen, G.F.W., Kruk, R.W., Langereis, C.G., Meijer, T., Pouwer, R., \& De Wolf, H., 2000. Stratigraphy and integrated facies analysis of the Eemian in Amsterdam-Terminal In: Van Kolfschoten, Th. \& Gibbard, P.L. (eds.): The Eemian - local sequences, global perspectives. Geologie en Mijnbouw / Netherlands Journal of Geosciences 79: 161-196 (this issue).

Van Voorthuysen, J.H., 1958, Foraminiferen aus dem Eemien (Riss-Würm-Interglazial) in der Bohrung Amersfoort I (Locus typicus). Mededelingen Geologische Stichting, Nieuwe Serie 11: 27-39.

Verbraeck, A., 1984. Blad Tiel West (39W) en blad Tiel Oost $(390)$. Toelichtingen bij de geologische kaart van Nederland 1:50.000. Rijks Geologische Dienst (Haarlem):334 pp.

Woldstedt, P., 1950. Norddeutschland and angrenzende Gebiete im Eiszeitalter. Koechler (Stuttgart): 464 pp.

Zagwijn, W.H., 1961. Vegetation, climate and radiocarbon datings in the Late Pleistocene of the Netherlands. Part I: Eemian and Early Weichselian. Mededelingen Geologische Stichting, Nieuwe Serie 14: 15-45.

Zagwijn, W.H., 1983. Sea-level changes in the Netherlands during the Eemian. Geologie en Mijnbouw 62: 437-450.

Zagwijn, W.H., 1996. An analysis of Eemian climate in Western and Central Europe. Quaternary Science Reviews 15: 451-469. 